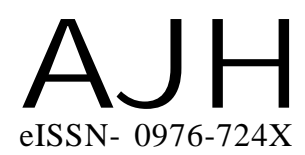

Received : 13.10 .2015

Revised : 04.11.2015

Accepted : 18.11.2015

Members of the Research Forum

Associated Authors:

${ }^{1}$ Department of Horticulture, College

of Agriculture, Junagadh

Agricultural University, JUNAGADH

(GUJARAT) INDIA

(Email : dvdelvadia@gmail.com)

Author for correspondence :

NIKETA PANJIAR

Department of Horticulture, College

of Agriculture, Junagadh

Agricultural University, JUNAGADH

(GUJARAT) INDIA

Email : niketa.panjiar@gmail.com
THEASIAN JOURNAL OF HORTICULTURE

Volume 10 | Issue 2 | December, 2015 | 251-256

Visit us -www.researchjournal.co.in

RESEARCH PAPER

DOI : 10.15740/HAS/TAJH/10.2/251-256

\title{
Standardization of recipe for the preparation of ready-to-serve beverage from tamarind cv. LOCAL
}

\section{NIKETA PANJIAR, D.V. DELVADIA ${ }^{1}$, MAYURI HADWANI ${ }^{1}$, V.J. BABARIYA $^{1}$ AND V.R. MALAM ${ }^{1}$}

ABSTRACT : A study was conducted to develop a ready-to-serve (RTS) beverage using tamarind dried fruit at Department of Horticulture, Junagadh Agricultural University, Junagadh during 2011-2012. The results of physico-chemical analysis revealed that TSS, acidity and reducing sugar content increased while the ascorbic acid content decreased with the advancement of storage period. The findings of microbial studies showed no total plate counts in the formulated beverages except treatments $T_{7}$ and $T_{12}$. Sensory evaluation of the samples showed that there were significant differences between treatments with respect to overall acceptance. From the results of quality assessments, the formulated beverage with 12 per cent blended juice of tamarind and ginger (3:1), 21 per cent TSS and 0.3 per cent acidity was found superior in quality and could be stored at ambient conditions for a period of five months without any significant changes in quality.

KEY WORDS : Tamarindus indica, RTS, Ginger blending

HOW TO CITE THIS ARTICLE : Panjiar, Niketa, Delvadia, D.V., Hadwani, Mayuri, Babariya, V.J. and Malam, V.R. (2015). Standardization of recipe for the preparation of ready-to-serve beverage from tamarind cv. LOCAL. Asian J. Hort., 10(2) : 251-256. 